\title{
HYDROXYL RADICAL BASED DEGRADATION OF CIPROFLOXACIN IN AQUEOUS SOLUTION
}

\author{
MURTAZA SAYED ${ }^{* 1,2}$, LUQMAN ALI SHAH', JAVED ALI KHAN², NOOR SAMAD SHAH ${ }^{2,3}$, HASAN M.KHAN*2, \\ RAFAQAT ALI KHAN ${ }^{1}$, ABDUR RAHMAN KHAN ${ }^{1}$, ASAD M.KHAN
}

\author{
${ }^{1}$ Department of Chemistry, COMSATS Institute of Information Technology, Abbotabad, 22060, Pakistan. \\ ${ }^{2}$ Radiation Chemistry Laboratory, National Centre of Excellence in Physical Chemistry, University of Peshawar, 25120, Peshawar. \\ ${ }^{3}$ Department of Environmental sciences, COMSATS Institute of Information Technology, Vehari, 61100, Pakistan.
}

\begin{abstract}
This study reports the degradation of ciprofloxacin (CIP) by means of ionizing radiations. Kinetic studies with aqueous concentrations of $4.6,10,15,17.9$ $\mathrm{mg} / \mathrm{L}$ reveals that degradation of CIP follows pseudo-first order kinetics and the decay constant increased with decrease in initial concentration of CIP. The removal efficiency, represented by G-value, decreased with increasing absorbed dose and increased with higher [CIP] ${ }_{0}$ concentration at a given absorbed dose. The effects of bubbling CIP solution with $\mathrm{N}_{2}, \mathrm{~N}_{2} \mathrm{O}$ or air on CIP degradation were also studied. The influence of various radical scavengers like tert-butanol, isopropanol, $\mathrm{HCO}_{3}^{-}, \mathrm{CO}_{3}{ }^{2-}, \mathrm{NO}_{3}^{-}$and $\mathrm{NO}_{2}^{-}$as radical scavengers in $\mathrm{N}_{2}$ - saturated solutions of $\mathrm{CIP}$ indicated that ${ }^{\circ} \mathrm{OH}$ were more closely associated with the radiolytic decomposition of CIP than other radicals, such as $\mathrm{e}^{-}$or ${ }^{\circ} \mathrm{H}$. The $\mathrm{pH}$ value of aqueous media played a crucial role in the degradation of CIP. It was observed that degradation efficiency was higher under acidic condition compared to degradation in natural or alkaline media. $\mathrm{F}^{-}, \mathrm{CH}_{3} \mathrm{COO}^{-}$and $\mathrm{HCOO}^{-}$were formed as a result of CIP degradation that were analyzed by ion-chromatography.
\end{abstract}

Keywords: Hydroxyl radical, ciprofloxacin, degradation, gamma-irradiation, kinetics

\section{INTRODUCTION}

The presence of antibiotics in the aquatic bodies provides a new challenge to drinking water, wastewater, and water reuse system [1-4]. Ciprofloxacin, a member from flouroquinolone group is widely used as humans and veterinary medicine [5]. The presence of these broad spectrum antibiotics in aquatic environments, may pose serious threats to the ecosystem and human health by causing proliferation of bacterial drug resistance [6,7]. Most flouroquinolones are not fully metabolized in the body and thus are excreted and introduced to the environment through wastewater effluents $[6,8]$. Advanced oxidation processes (AOPs), with highly reactive hydroxyl radical $\left({ }^{\circ} \mathrm{OH}\right)$ as the main oxidative species, provide an alternate technique to transform and decontaminate these soluble human antibiotics [1,9]. Radiation-induced decontamination of CIP and other toxic chemicals in water is a new and more promising technique [10]. This process has been found to be more economical and efficient than other waste water treatment processes [11].

The underlying principals behind gamma ray or electron beam treatment processes involve radiation chemistry of water, thoroughly studied and accepted technique. [12]. Irradiation of water using gamma ray can be explained by following equation, where the number in parenthesis represents the radiation yield (G-value) of each species per $100 \mathrm{eV}$ of absorbed energy [12]. (2.6)

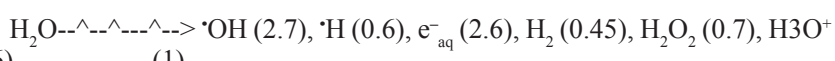
(1)

The most reactive species in Equation (1) are the oxidizing hydroxyl radicals $\left({ }^{\circ} \mathrm{OH}\right)$ and the reducing aqueous electrons $\left(\mathrm{e}^{-}\right)$and hydrogen atoms $\left(\mathrm{H}^{*}\right)$. High concentrations of these species can be produced in a very short interval of time and can react with target contaminant. Table 1 shows an estimate of the concentration of theses reactive species at different absorbed doses applied in the present study.

Table.1: Concentration of different species at various doses of gamma radiation.

\begin{tabular}{|c|c|c|c|c|}
\hline \multirow{2}{*}{ Dose (Gy) } & \multicolumn{4}{|c|}{ Concentration $(\mathrm{mM})$} \\
\cline { 2 - 5 } & $\mathrm{OH}$ & $\mathrm{H}$ & $\mathrm{e}_{\text {aq }}^{-}$ & $\mathrm{H}_{2} \mathrm{O}_{2}$ \\
\hline 145 & 0.0406 & 0.0087 & 0.03915 & 0.01015 \\
\hline 290 & 0.0812 & 0.0174 & 0.0783 & 0.0203 \\
\hline 435 & 0.1218 & 0.0261 & 0.11745 & 0.03045 \\
\hline 580 & 0.1624 & 0.0348 & 0.1566 & 0.0406 \\
\hline 870 & 0.2436 & 0.0522 & 0.2349 & 0.0609 \\
\hline
\end{tabular}

The present study focused on the use of gamma radiations as an AOP to degrade CIP and to determine the role of ${ }^{\circ} \mathrm{OH}$ in the degradation of CIP by means of radical scavengers experiments. The main objectives of the present study were: (1) to study the decomposition of ciprofloxacin (CIP) in water using gamma radiations; (2) to investigate the decomposition kinetics of CIP; and (3) to evaluate the efficiency of ${ }^{\circ} \mathrm{OH}$ in the degradation of CIP removal using radical promoters and scavengers, often present in water.

\section{EXPERIMENTAL}

2.1 Chemicals and reagents

All of the chemical used (tert-butanol, iso-propanol, sodium carbonate, sodium bicarbonate, sodium nitrate, sodium nitrite, perchloric acid, sodium hydroxide) were of high-purity analytical grade reagents supplied by SigmaAldrich. The ultrapure water was obtained from a Milli-Q ${ }^{\circledR}$ system (Millipore). Nitrogen and nitrous oxide gases used in the present study were of at least $99.99 \%$ purity.

Ciprofloxacin $(100 \%)$ used in this study was supplied by Sigma-Aldrich. The chemical structure of this compound is shown in Fig.1.

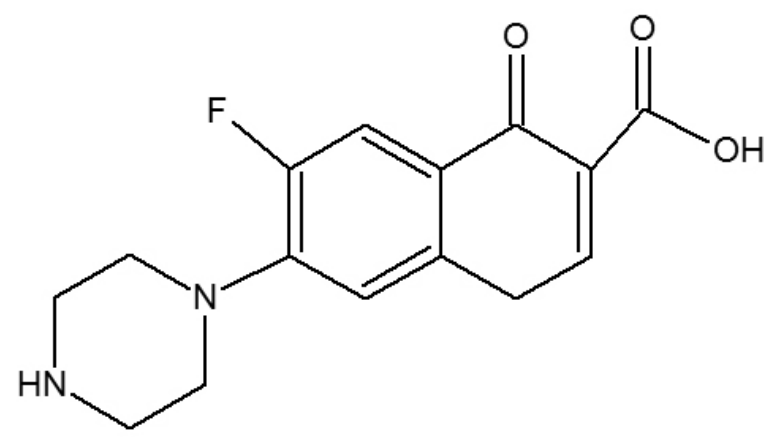

Fig. 1: Chemical Structure of Ciprofloxacin.

\section{$1.2 \quad$ Experimental procedures}

1.2.1 Sample preparation

CIP solution at initial concentration of $4.6 \mathrm{mg} / \mathrm{L}$ was prepared by dissolving weighted amount of solid CIP in ultrapure water. The different additives (iso-propanol, tert-butanol, $\mathrm{CO}_{3}{ }^{2-}, \mathrm{HCO}_{3}^{-}, \mathrm{NO}_{3}^{-}$, and $\mathrm{NO}_{2}^{-}$) of different concentrations were added into $\mathrm{CIP}$ aqueous solution to examine their effects on CIP degradation. $\mathrm{HClO}_{4}(0.05 \mathrm{~mol} / \mathrm{L})$ or $\mathrm{NaOH}(0.05 \mathrm{~mol} / \mathrm{L})$ were added into $4.6 \mathrm{mg} / \mathrm{L}$ CIP solution to make solution of desired $\mathrm{pH}$ and to test the effect of $\mathrm{pH}$ value on degradation efficiency. CIP solutions at different concentrations were also prepared to test the effect of initial concentration of $\mathrm{CIP}$ on degradation at the given radiation dose. 
2.2.2 Irradiation procedures and bubbling of CIP solution by $\mathrm{N}_{2}$ or $\mathrm{N}_{2} \mathrm{O}$ gases

The irradiation source used for irradiation studies was a Co-60 gammaray source (Issledovatol, former USSR) available at NIFA, Tarnab, Peshawar, Pakistan. The source was calibrated by using aqueous ferrous sulfate (Fricke dosimetry) solution [12]. The dose rate was found to be $296 \mathrm{~Gy} / \mathrm{hr}$.

$\mathrm{N}_{2}$-sauturated experiments were conducted in $250 \mathrm{~mL}$ glass vessel, where $\mathrm{N} 2$-gas was passed through CIP solution for at least 25 minutes. For N2O saturation of CIP solution, same procedure was applied, replacing $\mathrm{N} 2$ by $\mathrm{N} 2 \mathrm{O}$ gas. The purity of $\mathrm{N}_{2}$ and $\mathrm{N}_{2} \mathrm{O}$ gasses used in this study was $99.999 \%$.

2.3 Analytical methods

Analysis of CIP was performed using high performance liquid chromatography (Agilent 1200 series HPLC, Agilent Technologies, USA), equipped with UV detector. The separation was achieved using reversed phase C-18 column, with water/methanol/acetonitrile/1\% acetic acid (15/15/20/50, $\mathrm{V} / \mathrm{V}$ ) as mobile phase in isocratic mode at flow rate of $1 \mathrm{ml} \mathrm{min}^{-1}$. The evaluation of UV-Vis absorption spectra of CIP in aqueous solution before and after irradiation was recorded by Lambda-800 UV-Visible Spectrophotometer (Perkin Elmer Instruments, USA). For the analysis of by-products, like $\mathrm{F}^{-}$, $\mathrm{CH}_{3} \mathrm{COO}^{-}$and $\mathrm{HCOO}^{-}$, Metrohm Ion- Chromatograph (IC) was used. Triplicate samples were prepared and analyzed for each sample.

\subsection{Calculation of G-Value and dose constants}

The G-value is defined as the number of molecules of products formed or of reactant destroyed, by absorbing $100 \mathrm{eV}$ of energy, it can be calculated using the following equation [13].

$$
\mathrm{G}=\frac{\mathrm{R}\left(6.02 \times 10^{23}\right)}{\mathrm{D}\left(6.24 \times 10^{16}\right)}
$$

Where $\mathrm{R}$ is the change in the concentration of reactant, CIP (M), D is the absorbed dose (Gy), $6.02 \times 10^{23}$ is the Avogadro's number and $6.24 \times 10^{16}$ the conversion factor from Gy to $100 \mathrm{eV} / \mathrm{L}$.

The dose constant, $\mathrm{k}$, was calculated from the slope of the natural logarithm (ln) of the organic pollutant concentration in M versus dose (Gy). Dose constants were used to calculate dose required for $50 \%$ and $90 \%$ CIP degradation ( $\mathrm{D}_{0.5}$ and $\mathrm{D}_{0.9}$ values) by using Eqs. (3) and (4):

$$
\begin{aligned}
& \mathrm{D}_{0.5}=\frac{\ln 2}{k} \\
& \mathrm{D}_{0.9}=\frac{\ln 10}{k}
\end{aligned}
$$

$\mathrm{D}_{0.5}$ and $\mathrm{D}_{0.9}$ were used for the analysis of solute removal [14].

\section{RESULTS AND DISCUSSION}

\subsection{Degradation of CIP by ionizing radiations}

During ionizing irradiation, the reactions between reactive radicals $(\cdot \mathrm{OH}$, $\left.\mathrm{e}^{-}, \cdot \mathrm{H}\right)$ and any additive occur in aqueous solution as follows: In aerated media, the reducing species ${ }^{\circ} \mathrm{H}$ and e ea ${ }^{-}$are converted into $\mathrm{HO}_{2}{ }_{2}$ and $\mathrm{O}_{2}{ }^{-}$because of their fast reactions given by Eqs. (5) and (6); under acidic conditions, the $\mathrm{H}^{+}$ion reacts with $\mathrm{e}_{\text {aq }}^{-}$to produce $\mathrm{H}^{\circ}$, as by Eq. (7); $\mathrm{HO}_{2}^{-}$and its conjugate base $\mathrm{O}_{2}^{-}$exist in a pH-dependent equilibrium as given by Eq. (8);

$$
\begin{array}{ll}
\mathrm{H}^{-}+\mathrm{O}_{2} \rightarrow \mathrm{HO}^{-} & k=2.1 \times 10^{10} \mathrm{~L} / \mathrm{mol} . \mathrm{s} \\
\mathrm{e}^{-}+\mathrm{O}_{2} \rightarrow \mathrm{O}^{-} & k=1.9 \times 10^{10} \mathrm{~L} / \mathrm{mol} . \mathrm{s} \\
\mathrm{e}^{-\mathrm{aq}}+\mathrm{H}^{+} \rightarrow \mathrm{H}^{2} & k=2.3 \times 10^{10} \mathrm{~L} / \mathrm{mol} . \mathrm{s} \\
\mathrm{HO}_{2} \mathrm{O}_{2}^{-}+\mathrm{H}^{+} & \mathrm{pka}=4.88
\end{array}
$$

Eqs. (9)- (11) may also occur depending on experimental conditions.

$$
\begin{aligned}
& \mathrm{HO}_{2}+\mathrm{O}^{-} \rightarrow \mathrm{H}_{2} \mathrm{O}_{2}+\mathrm{O}_{2}(\mathrm{pH}<7) \quad k=9.7 \times 10^{7} \mathrm{~L} / \mathrm{mol} . \mathrm{s} \\
& \mathrm{HO}_{2}^{2}+\mathrm{HO}_{2}^{2} \rightarrow \mathrm{H}_{2} \mathrm{O}_{2}+\mathrm{O}_{2} \quad k=8.3 \times 10^{5} \mathrm{~L} / \mathrm{mol} . \mathrm{s} \\
& \mathrm{H}^{+}+\mathrm{OH}^{-} \rightarrow \mathrm{e}^{-}{ }_{\text {aq }}+\mathrm{H}_{2} \mathrm{O} \quad k=2.2 \times 10^{7} \mathrm{~L} / \mathrm{mol} . \mathrm{s}
\end{aligned}
$$

Aqueous solution of $4.6 \mathrm{mg} / \mathrm{L}$ CIP was irradiated with radiation doses of $0,145,290,435,870$ Gy. Fig. 2 shows the UV-absorbance spectra of CIP solution before and after irradiation at $200-400 \mathrm{~nm}$ (Fig. 2a) and decrease in concentration of CIP as a result of after gamma ray irradiation (Fig. 2b). The results showed that the UV-absorbance and thus the conc. of CIP in the 200 $400 \mathrm{~nm}$ region decreased with increase of radiation dose. At radiation dose of
$870 \mathrm{~Gy}, 4.6 \mathrm{mg} / \mathrm{L}$ of CIP was almost completely degraded as shown in Fig. 2 b.
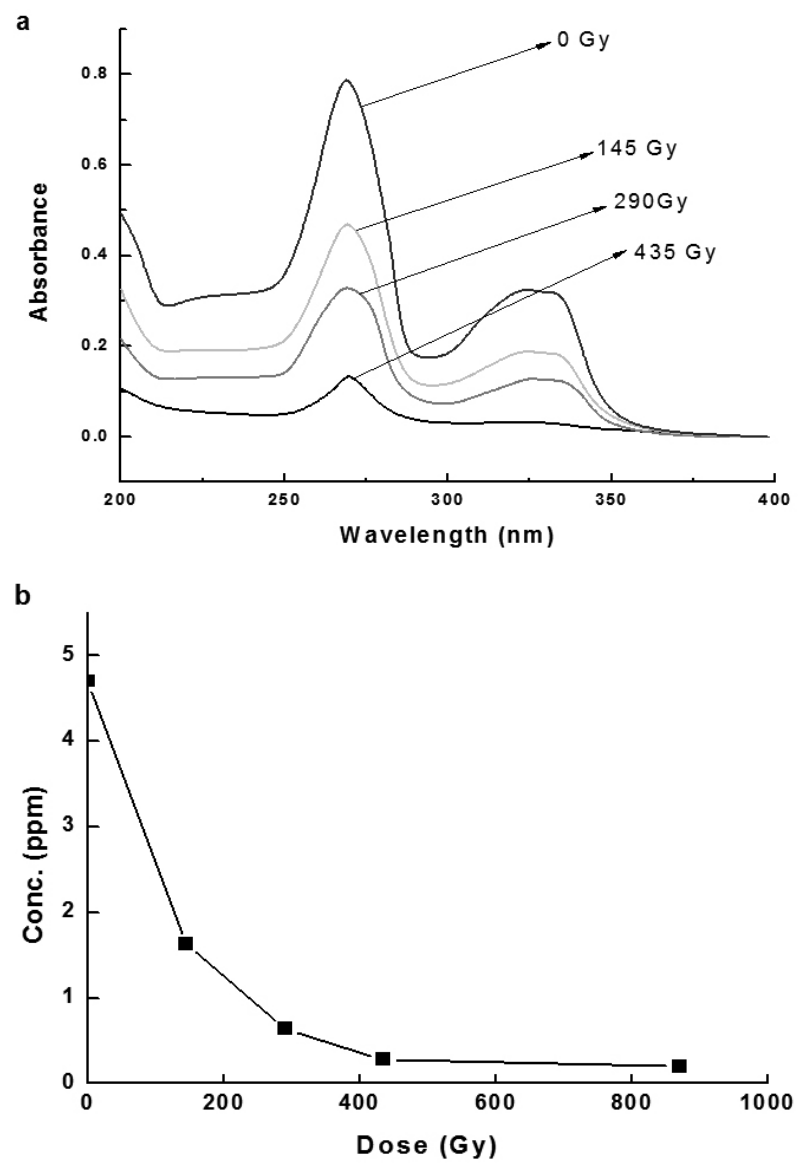

Fig. 2: The UV-absorbance spectra of CIP before and after irradiation at 200-400nm (a) and decrease in CIP concentration after gamma-ray Irradiation (b)

According to Eq. (2), the G-values of CIP ( $4.6 \mathrm{mg} / \mathrm{L})$ at different radiation doses were calculated as shown in Table 2. The G-values decreased with increasing radiation dose, a trend that has been reported in several other studies [15-17]. Firstly, this trend can be explained by competition for solute molecules (CIP) between the reactive species produced during radiolysis of water. With increasing radiation dose, greater competition occurs between the reactive radicals, resulting in decrease of G-values. Secondly, there is possibility of competition for reactive radicals between the parent compound (CIP) and the reaction by-products [17]. The third possibility is the radical-radical recombination reactions, including ${ }^{\circ} \mathrm{OH}, \mathrm{e}^{-},{ }^{\circ} \mathrm{H}$ also increases with increasing radiation dose [15] as shown by reactions such as given in Eqs. (12-15), so the radical concentration for interaction with CIP reduced.

Table 2: The G-Value of CIP removal at different absorbed dose.

\begin{tabular}{|c|c|c|c|c|}
\hline Absorbed dose (Gy) & 145 & 290 & 435 & 870 \\
\hline $\begin{array}{c}\text { G value } \\
\text { (molecules/100 ev) }\end{array}$ & 0.5635 & 0.3582 & 0.2671 & 0.1402 \\
\hline
\end{tabular}

$\cdot \mathrm{OH}+\cdot \mathrm{OH} \rightarrow \mathrm{H}_{2} \mathrm{O}$

$\cdot \mathrm{OH}+{ }^{\circ} \mathrm{H} \rightarrow \mathrm{H}_{2} \mathrm{O}$

$\cdot \mathrm{OH}+\mathrm{e}^{-} \rightarrow \mathrm{OH}^{-}$

$\mathrm{H}_{2} \mathrm{O}+\mathrm{H}^{\mathrm{aq}}+\mathrm{e}_{\text {aq }}^{-} \rightarrow \mathrm{H}_{2}+\mathrm{OH}$

$k=5.5 \times 10^{9} \mathrm{~L} / \mathrm{mol} . \mathrm{s}$

$k=7.0 \times 10^{9} \mathrm{~L} / \mathrm{mol} . \mathrm{s}$

$k=3.0 \times 10^{10} \mathrm{~L} / \mathrm{mol} . \mathrm{s}$

$k=2.5 \times 10^{10} \mathrm{~L} / \mathrm{mol} . \mathrm{s}$

The efficiency of irradiation process for the decomposition of CIP was compared between the percentage removal (\%) and G-values as shown in Fig. 3 . 


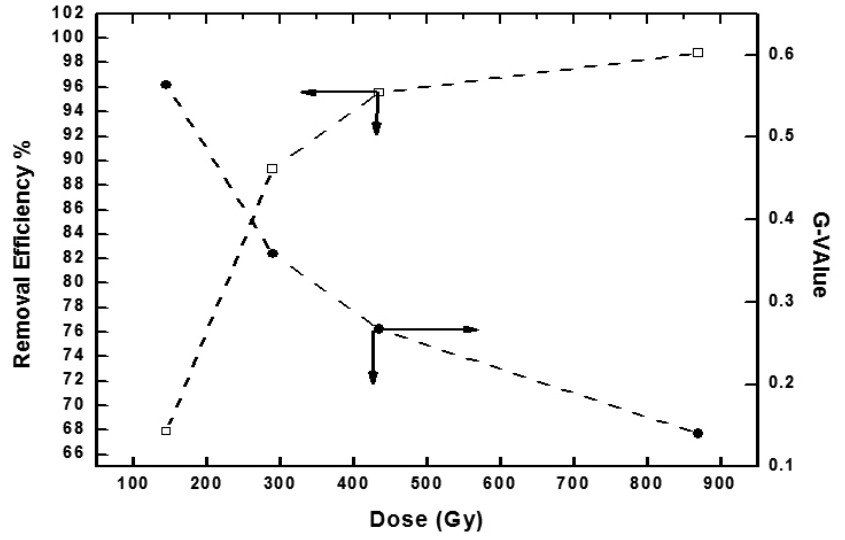

Fig. 3: Calculated G-values and Percentage removal efficiencies of CIP using gamma irradiation. The initial aqueous CIP concentration was $4.6 \mathrm{mg} / \mathrm{L}$.

\subsection{Effect of dissolved oxygen, $\mathrm{N}_{2}$-saturated and $\mathrm{N}_{2} \mathrm{O}$-satureted gases on} CIP degradation.

Fig. 4 shows the effect of dissolved oxygen, $\mathrm{N}_{2}$-saturated and $\mathrm{N}_{2} \mathrm{O}$-saturated gases on CIP degradation by gamma irradiation. In this figure the fractions of $\mathrm{CIP}$ at a given radiation dose $\left(\mathrm{C} / \mathrm{C}_{0}\right)$ has been plotted against radiation dose (where $\mathrm{C}$ is the conc. Of CIP after irradiation and $\mathrm{C}_{0}$ is the initial conc. of CIP). It is clear from Fig. 4 that CIP was degraded in all the three conditions and degradation efficiency increased with the increase in radiation dose. However, the degradation efficiency in the solution saturated with nitrous oxide was relatively higher than that in the solution saturated with air, and the latter was greater than degradation efficiency in the solution saturated with nitrogen.

Table 3: Effect of Irradiation on dose constant, $\mathrm{D}_{0.5}$ and $\mathrm{D}_{0.9}$ at different concentrations of CIP solution.

\begin{tabular}{|c|c|c|c|}
\hline $\begin{array}{c}\text { Concentration } \\
(\mathbf{m g} / \mathbf{L})\end{array}$ & $\begin{array}{c}\text { Dose } \\
\text { constant (k) }\end{array}$ & $\mathbf{D}_{\mathbf{0 . 5}}(\mathbf{G y})$ & $\mathbf{D}_{\mathbf{0 . 9}}(\mathbf{G y})$ \\
\hline 4.6 & $4.9 \times 10^{-3}$ & 138.62 & 460.51 \\
\hline 10 & $2.9 \times 10^{-3}$ & 231.04 & 767.52 \\
\hline 15 & $1.9 \times 10^{-3}$ & 346.57 & 1151.29 \\
\hline 17.9 & $1.6 \times 10^{-3}$ & 433.21 & 1439.11 \\
\hline
\end{tabular}

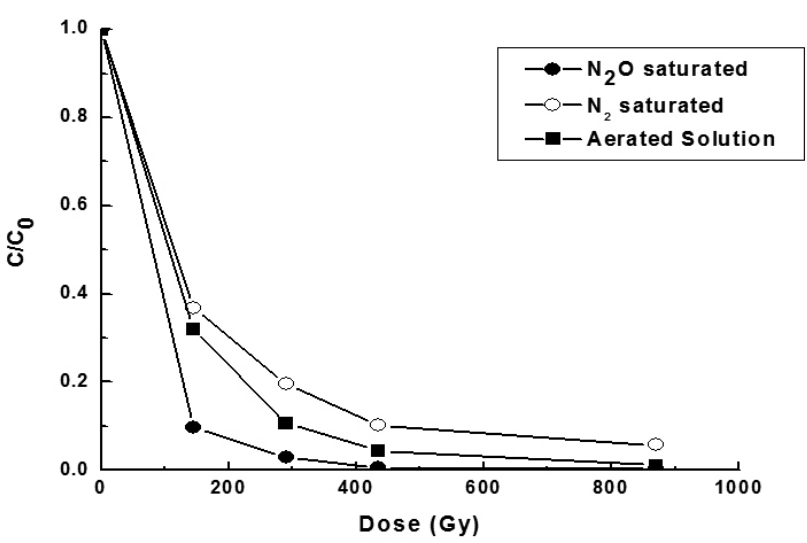

Fig. 4: Degradation of aqueous CIP solution in air, $\mathrm{N}_{2}$, or $\mathrm{N}_{2} \mathrm{O}$ saturated solution by gamma irradiation.

In aqueous solution of CIP saturated with nitrogen, all of $\mathrm{e}_{\mathrm{aq}}^{-},{ }^{-} \mathrm{H}$ and ${ }^{\circ} \mathrm{OH}$ may react with CIP. Whereas in the aqueous solution saturated with nitrous oxide, the conc. $\mathrm{Of} \mathrm{OH}$ is increased due to conversion of $\mathrm{e}_{\mathrm{aq}}{ }^{-}$to $\mathrm{OH}$ as shown in Eq. (16).

$$
\mathrm{e}_{\mathrm{aq}}{ }^{-}+\mathrm{N}_{2} \mathrm{O}+\mathrm{H}_{2} \mathrm{O} \rightarrow \cdot \mathrm{OH}+\mathrm{N}_{2}+\mathrm{OH}^{-} \quad k=9.1 \times 10^{9} \mathrm{~L} / \mathrm{mol} . \mathrm{s}
$$

Under this condition the concentration of $\mathrm{H}$ is only $1 / 10$ of that of ${ }^{\circ} \mathrm{OH}$ and $\cdot \mathrm{OH}$ is the main radical that reacts with CIP.

In aerated solution, oxygen reacts with $\mathrm{e}_{\text {aq }}{ }^{-}$and ${ }^{\circ} \mathrm{H}$ by fast reactions (Eqs. $(5,6)$ ), forming $\mathrm{O}_{2}{ }^{-}$and $\mathrm{HO}_{2} \cdot$. However ${ }^{\circ} \mathrm{OH}$ radical still can react with CIP. These radicals can then react with CIP to increase the degradation efficiency of CIP. Therefore, it appears that among the three radicals, the ${ }^{\circ} \mathrm{OH}$ radicals are more effective in degradation of CIP.

$3.3 \mathrm{CIP}$ degradation in the presence of ${ }^{\circ} \mathrm{OH}$ scavengers (2-PrOH, tert$\mathrm{BUOH}, \mathrm{CO}_{3}^{2-}, \mathrm{NO}_{2}^{-}, \mathrm{HCO}_{3}^{-}$and $\left.\mathrm{NO}_{3}^{-}\right)$

Iso-propanol (2-PrOH) can scavenge ${ }^{\circ} \mathrm{OH}$ and ${ }^{\circ} \mathrm{H}$ by the reactions shown in Eqs. (17) and (18) [18],whereas tert-BuOH can scavenge ${ }^{\circ} \mathrm{OH}$ by the reactions shown in Eq. (20) [18]:

$\cdot \mathrm{OH}+2-\mathrm{PrOH} \rightarrow\left(\mathrm{CH}_{3}\right)_{2} \cdot \mathrm{COH}+\mathrm{H}_{2} \mathrm{O} \quad k=1.9 \times 10^{9} \mathrm{~L} / \mathrm{mol} . \mathrm{s}$ (19)

$\mathrm{H}^{\bullet}+2-\mathrm{PrOH} \rightarrow\left(\mathrm{CH}_{3}\right)_{2}{ }^{\circ} \mathrm{COH}+\mathrm{H}_{2} \quad k=7.4 \times 10^{7} \mathrm{~L} / \mathrm{mol}$.s

$\cdot \mathrm{OH}+\mathrm{t}-\mathrm{BUOH} \rightarrow{ }^{2} \mathrm{CH}_{2} \mathrm{C}\left(\mathrm{CH}_{3}\right)_{2} \mathrm{OH}+\mathrm{H}_{2} \mathrm{O} k=6.0 \times 10^{8} \mathrm{~L} / \mathrm{mol} . \mathrm{s}$

Since both $\left(\mathrm{CH}_{3}\right)_{2}{ }^{\circ} \mathrm{COH}$ and ${ }^{\circ} \mathrm{CH}_{2} \mathrm{C}\left(\mathrm{CH}_{3}\right)_{2} \mathrm{OH}$ are relatively slow reacting species, $\mathrm{H}^{\cdot}$ and $\mathrm{e}_{\text {aq }}$ play the predominant role in the presence of tert-butanol while $\mathrm{e}^{-}$plays the crucial role in the presence of iso-propanol. Table 4 shows the degradation efficiency at different doses for these three conditions i.e., without scavenger, with the presence of $80 \mathrm{mM}$ iso-propanol, or $80 \mathrm{mM}$ of tertbutanol. This shows that ${ }^{\circ} \mathrm{OH}$ played the most important role in the degradation process while ${ }^{\circ} \mathrm{H}$ and hydrated electron only played minor role.

Table 4 shows the effects of $\mathrm{HCO}_{3}^{-}$and $\mathrm{NO}_{3}^{-}$on CIP degradation. The results showed that at the same absorbed dose the degradation efficiency was lower in the presence of $\mathrm{HCO}_{3}^{-}$and $\mathrm{NO}_{3}^{-}$than that in the absence of them. The reason was that in the presence of $\mathrm{HCO}_{3}^{-}, \mathrm{OH}$ could be rapidly scavenged by it as shown by Eq. (20). $\mathrm{NO}_{3}{ }^{-}$is a good scavenger of $\mathrm{e}_{\text {aq }}{ }^{-}$and it also inhibited the degradation processes of CIP [13].

$$
\begin{array}{lc}
\bullet \mathrm{OH}+\mathrm{HCO}_{3}^{-} \rightarrow \mathrm{CO}_{3}^{-}+\mathrm{H}_{2} \mathrm{O} & k=8.5 \times 10^{8} \mathrm{~L} / \mathrm{mol} . \mathrm{s} \\
\mathrm{NO}_{3}{ }^{-}+\mathrm{e}_{\mathrm{aq}}{ }^{-} \rightarrow \mathrm{NO}_{3}{ }^{-2}\left(\rightarrow \mathrm{NO}_{2}{ }^{-}+2 \mathrm{OH}^{-}\right) & k=9.7 \times 10^{9} \mathrm{~L} / \mathrm{mol} . \mathrm{s}
\end{array}
$$

When $\mathrm{CO}_{3}{ }^{2-}$ and $\mathrm{NO}_{2}^{-}$were added, the removal efficiency of CIP was relatively lower than that in the absence of them at the same radiation dose. It might be the reason that ${ }^{\circ} \mathrm{OH}$ was quickly scavenged by $\mathrm{NO}_{2}{ }^{-}$and $\mathrm{CO}_{3}{ }^{2-}$ as shown by Eqs. $(22,23)[13,18]$.

$$
\begin{array}{ll}
\mathrm{CO}_{3}^{2-}+\cdot \mathrm{OH}=\mathrm{CO}_{3}^{-}+\mathrm{OH}^{-} & k=3.9 \times 10^{8} \mathrm{~L} / \mathrm{mol} . \mathrm{s} \\
\mathrm{NO}_{2}^{-{ }^{-}}+\cdot \mathrm{OH}=\mathrm{NO}_{2}+\mathrm{OH}^{-} & k=1.0 \times 10^{10} \mathrm{~L} / \mathrm{mol} . \mathrm{s}
\end{array}
$$

In the presence of these additives, there is a competition between these additives and CIP for ${ }^{\circ} \mathrm{OH}$. Since, the reaction between $\mathrm{NO}_{2}^{-}$and ${ }^{\circ} \mathrm{OH}$ is very fast (Eq.23), relatively small amount of ${ }^{\circ} \mathrm{OH}$ is left to degrade CIP resulting in lower degradation as compared to degradation in presence of $\mathrm{CO}_{3}{ }^{2-}$ or in absence of any additives (Table 4).

Both $\mathrm{NO}_{2}^{-}$and $\mathrm{CO}_{3}{ }^{2-}$ are the scavengers of $\mathrm{e}^{-}$also and they inhibited the degradation process of CIP as shown by Eqs. $(24,25)[18,19]$.

$$
\begin{array}{ll}
\mathrm{NO}_{2}^{-}+\mathrm{e}_{\text {aq }}^{-}=\mathrm{NO}_{2}^{2-} & k=4.1 \times 10^{9} \mathrm{~L} / \mathrm{mol} . \mathrm{s} \\
\mathrm{CO}_{3}^{2-}+\mathrm{e}_{\text {aq }}=\text { products } & k=3.9 \times 10^{5} \mathrm{~L} / \mathrm{mol} . \mathrm{s}
\end{array}
$$

3.4 Kinetic study for the radiolytic degradation of CIP

As shown in Fig. $2 \mathrm{~b}$ the concentration of CIP decreases exponentially with the absorbed doses, which can be represented by Eq.26 [20, 21].

$$
\mathrm{C}=\mathrm{C}_{0} \mathrm{e}^{-k \mathrm{D}}
$$

Where $\mathrm{C}_{0}$ and $\mathrm{C}$ represents initial and final concentrations of CIP before and after irradiation, respectively. ' $k$ ' is the dose constant and ' $D$ ' the absorbed dose. This Eq. (26) can be re-arranged to pseudo-first-order reaction as;

$$
-\ln \left(\mathrm{C} / \mathrm{C}_{0}\right)=k \mathrm{D}
$$

Eq. (27) was used to calculate the dose constant from a linear least-squares fit of the experimental data.

Batch kinetic experiments were performed to study the dependency of Initial concentrations of 4.6, 10, 15 and $17.9 \mathrm{mg} \mathrm{L}^{-1}$, and absorbed doses ranging from 0 to $870 \mathrm{~Gy}$ were used for these experiments. The aqueous CIP solutions were prepared at room temperature $\left(\right.$ ca. $25{ }^{\circ} \mathrm{C}$ ) and initial $\mathrm{pH}$ of solution was 6.2 . 
Table 4: \% degradation of CIP in the presence of radical scavengers (2-PrOH, tert- $\mathrm{BuOH}, \mathrm{CO}_{3}{ }^{2-}, \mathrm{NO}_{2}^{-}, \mathrm{HCO}_{3}^{-}$and $\mathrm{NO}_{3}^{-}$)

\begin{tabular}{|c|c|c|c|c|c|c|c|}
\hline $\begin{array}{l}\text { Absorbed } \\
\text { dose (Gy) }\end{array}$ & Blank & $\begin{array}{c}\text { \% degradation } \\
\text { in the presence } \\
\text { of tert- } \mathrm{BuOH}\end{array}$ & $\begin{array}{c}\% \text { degradation } \\
\text { in the presence } \\
\text { of iso-PrOH }\end{array}$ & $\begin{array}{c}\% \text { degradation } \\
\text { in the presence } \\
\text { of } \mathrm{CO}_{3}{ }^{2-}\end{array}$ & $\begin{array}{c}\% \text { degradation } \\
\text { in the presence } \\
\text { of } \mathrm{NO}_{2}^{-}\end{array}$ & $\begin{array}{c}\% \text { degradation } \\
\text { in the presence } \\
\text { of } \mathrm{HCO}_{3}^{-}\end{array}$ & $\begin{array}{c}\text { \% degradation } \\
\text { in the presence of } \\
\mathrm{NO}_{3}^{-}\end{array}$ \\
\hline 0 & 0 & 0 & 0 & 0 & 0 & 0 & 0 \\
\hline 145 & 65.41 & 11.44 & 3.89 & 25.14 & 4.55 & 31.43 & 42.95 \\
\hline 290 & 86 & 22.57 & 11.8 & 50.89 & 9.85 & 52.56 & 60.47 \\
\hline 435 & 93.9 & 32.6 & 23.32 & 73.79 & 12.09 & 67.02 & 69.75 \\
\hline 870 & 96.3 & ----- & ------ & 90.11 & 14.04 & 80.87 & 81.95 \\
\hline
\end{tabular}

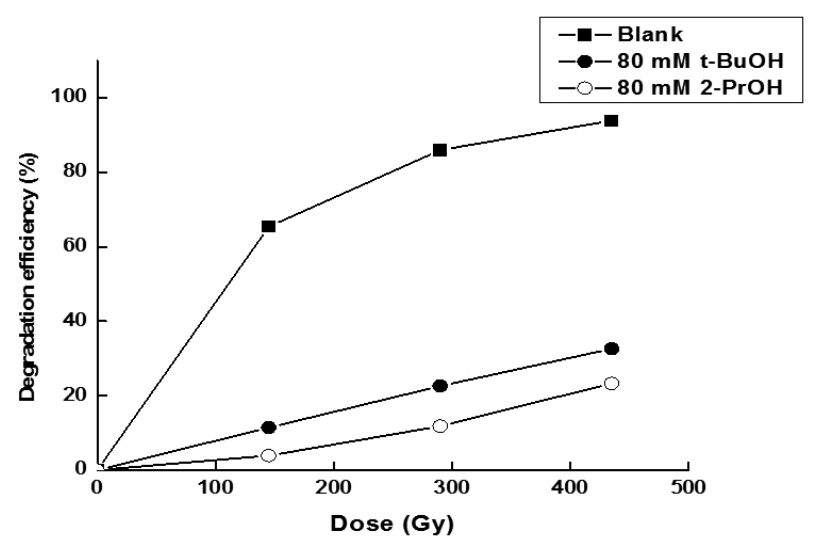

Fig. 5: Effect of 2-PrOH and t-BuOH additives on CIP degradation.

Fig.6 shows the results of the radiolytic decomposition of CIP at four different initial concentrations. At lower concentrations, the decomposition rates (based on decrease in $\left(\mathrm{C} / \mathrm{C}_{0}\right)$ ) were faster, as shown in Fig. 6A. Starting with conc. of $4.6 \mathrm{mg} / \mathrm{L}$ more than $90 \%$ CIP was degraded with less than 800 Gy. The experimental results were well fitted to the pseudo-first order reaction model given by (Eq. (27)). The value of decay constants $(k)$ at CIP different initial concentrations of $4.6,10,15$ and $17.9 \mathrm{mgL}^{-1}$ were $0.005,0.003,0.002$ and $0.0016 \mathrm{~Gy}^{-1}$, respectively. The value of decay constant decreased as the CIP concentration increased which means that CIP can be removed at faster rate at lower concentrations, which can also be verified by calculating the radiation dose required for $50 \%\left(\mathrm{D}_{05}\right)$ and $90 \%\left(\mathrm{D}_{\mathrm{g}}\right)$ removal of CIP as shown in Table 3 . These results are similar with the previously reported results $[21,22]$.

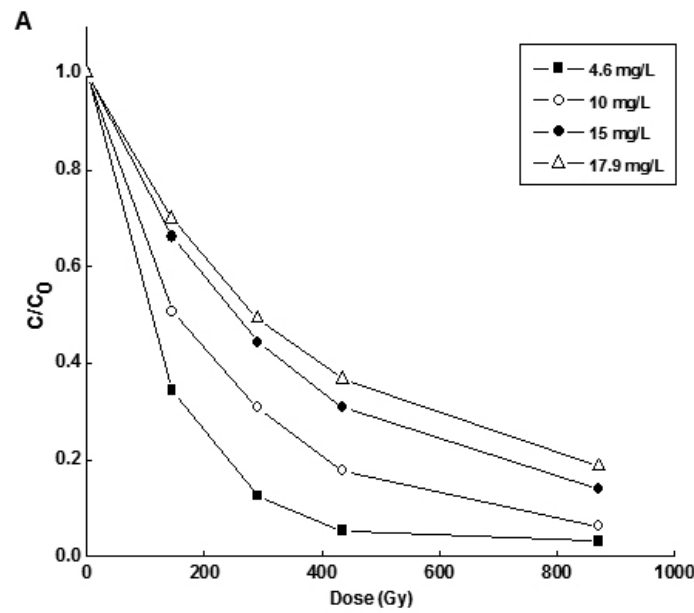

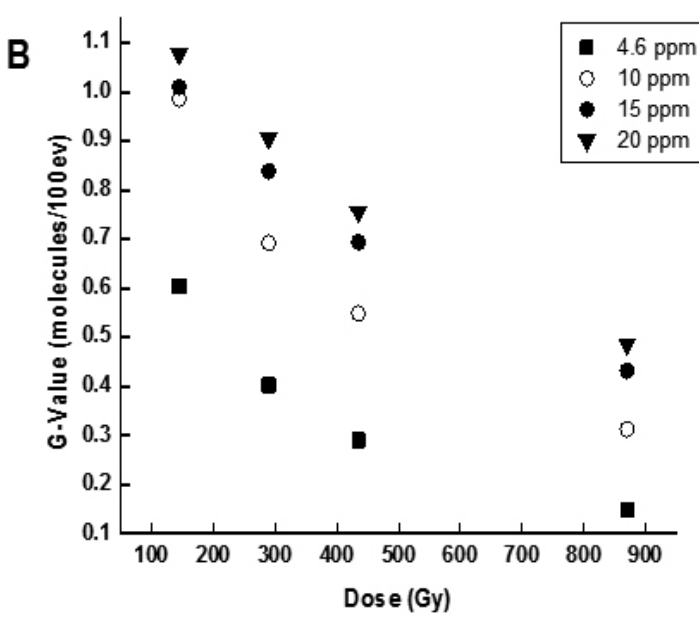

Fig. 6: Kinetic results for the radiolytic degradation of CIP at different initial concentrations. (A) Removal of CIP at different initial conc. vs. irradiation doses and (B) the G-value at different initial CIP concentrations.

The G-values calculated for four different initial CIP concentrations of CIP versus absorbed dose are presented in fig. 6B. As shown in Fig. 3, the G-values decreased with increasing radiation dose. However, for a given radiation dose, the G-values increased with the higher initial CIP concentration, which is similar to previously reported results with chloroform and MTBE [17]. This can be explained by the fact that at higher CIP concentrations, the reactive radicals have a greater chance of reacting with CIP molecules, leading to higher removal efficiency, represented by higher G-values.

\subsection{Effect of solution $\mathrm{pH}$}

Fig. 7 shows the influence of $\mathrm{pH}$ of aqueous medium on CIP degradation. The degradation was enhanced in acidic $(\mathrm{pH} 3.56)$ conditions. The reason is that, under acidic condition, hydrated electron is converted to ${ }^{\circ} \mathrm{H}$ and the relative concentration of ${ }^{\circ} \mathrm{H}$ was much higher (Eq. (7)). On the other hand in alkaline media, ${ }^{\circ} \mathrm{H}$ reacts with $\mathrm{OH}^{-}$to generate e - (Eq. (12)), so increasing the concentration of $\mathrm{e}^{-}$and thus enhancing the probability of recombination between $\mathrm{e}^{-}$and ${ }^{\circ} \mathrm{OH}$ (Eq. (16)). This results in decrease of ${ }^{\circ} \mathrm{OH}$ concentration, and thus the degradation efficiency of CIP decreased at higher $\mathrm{pH}$ values [23].

\section{By-Product Analysis}

The gamma irradiation can degrade CIP effectively producing, fluoride $\left(\mathrm{F}^{-}\right)$, acetate $\left(\mathrm{CH}_{3} \mathrm{COO}^{-}\right)$and formate $\left(\mathrm{HCOO}^{-}\right)$ions. Concentration of $\mathrm{F}^{-}, \mathrm{CH}_{3} \mathrm{COO}^{-}, \mathrm{HCOO}^{-}$were determined using Metrohm 800 series ion chromatograph, equipped with electrical conductivity detector. The column used was Assup-5 (250/4.0mm), with $3.2 \mathrm{mM} \mathrm{Na}_{2} \mathrm{CO}_{3} / 1 \mathrm{mM} \mathrm{NaHCO}_{3} / 50 \mathrm{mM}$ $\mathrm{H}_{2} \mathrm{SO}_{4} /$ water at flow rate of $1 \mathrm{~mL} / \mathrm{min}$. As shown in Fig.8, with the increase in the absorb dose the CIP concentration decreased while the concentration of $\mathrm{F}^{-}, \mathrm{CH}_{3} \mathrm{COO}^{-}$and $\mathrm{HCOO}^{-}$ions increased. Acetate ion was the major product of CIP degradation while the concentration of formate ion and fluoride was relatively small. After dose of $600 \mathrm{~Gy}$ the concentration of acetate ions are also starting to decrease, probably because of degradation of acetate ions as a result of irradiation. 


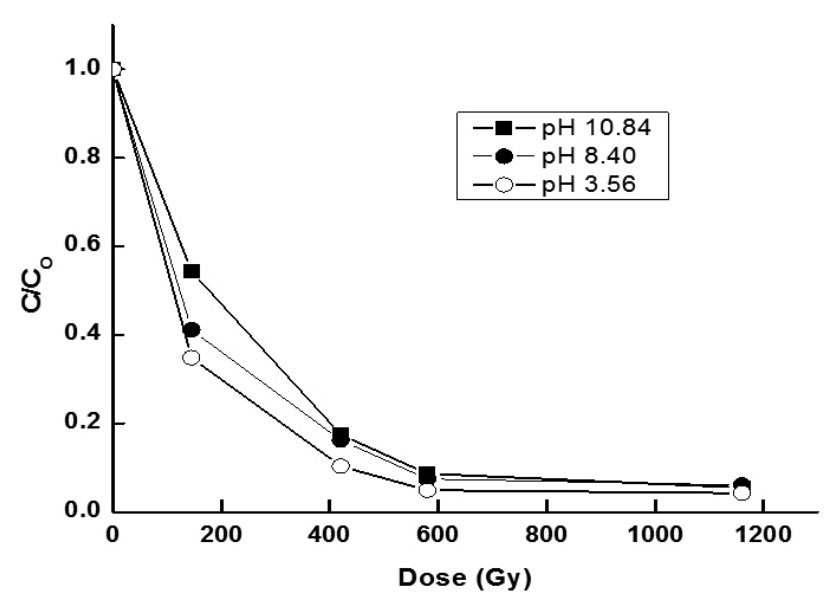

Fig.7: Effect of $\mathrm{pH}$ on degradation of CIP by gamma irradiation.

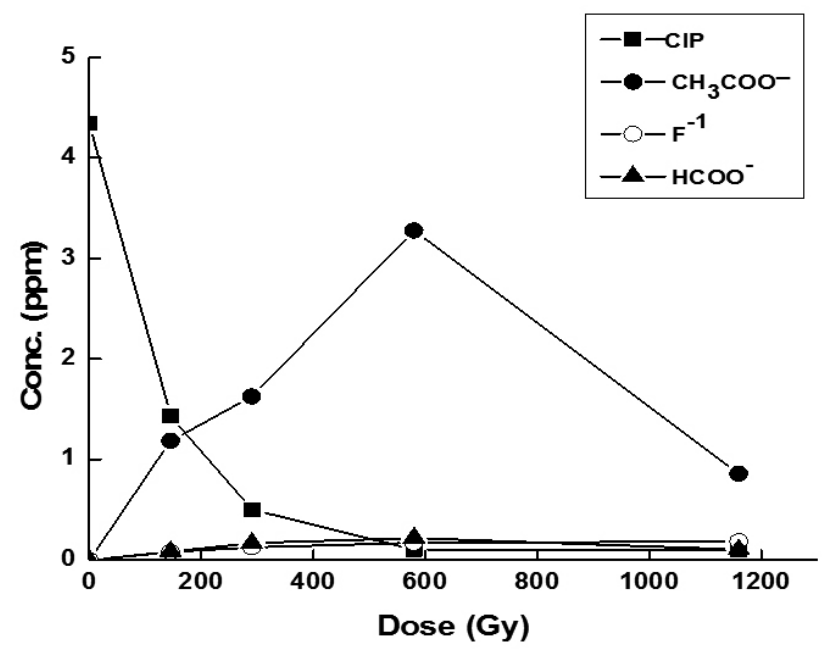

Fig. 8: Changes in the concentration of $\mathrm{CIP}, \mathrm{F}^{-1}, \mathrm{CH}_{3} \mathrm{COO}^{-}, \mathrm{HCOO}^{-}$with absorbed doses.

\section{CONCLUSIONS}

The results of this study showed that CIP was degraded more in $\mathrm{N}_{2} \mathrm{O}-$ saturated solution as compared to $\mathrm{N}_{2}$-saturated and aerated solutions. The radical scavenger experiments indicated that ${ }^{\circ} \mathrm{OH}$ is mainly responsible for the radiolytic decomposition of CIP. The results of kinetic study showed that radiolytic oxidation of CIP followed pseudo first-order reaction. With respect to G-value, two patterns were observed in our study. The removal efficiencies as represented by $\mathrm{G}$-values decreased with higher irradiation doses. At a given dose, the G-values increased with increasing aqueous CIP concentration. The $\mathrm{pH}$ value also affect the CIP degradation efficiency, the degradation yield was higher in acidic conditions as compared to neutral and alkaline media.

In conclusion the application of radiation technology shows promising results in the treatment of industrial and municipal effluents containing various antibiotic compounds.

\section{REFERENCES}

1. Ikehata K, Jodeiri Naghashkar N, Gamal El-Din M. Degradation of Aqueous Pharmaceuticals by Ozonation and Advanced Oxidation Processes: A Review. Ozone-Sci Eng 28:353-414 (2006).

2. Song W, Cooper WJ, Mezyk SP, Greaves J, Peake BM. Free radical destruction of beta-blockers in aqueous solution. Environ Sci Technol 42:1256-1261 (2008).

3. An T, Yang H, Song W, Li G, Luo H, Cooper WJ. Mechanistic considerations for the advanced oxidation treatment of fluoroquinolone pharmaceutical compounds using $\mathrm{TiO}_{2}$ heterogeneous catalysis. $J$ Phys Chem C 114:2569-2575 (2010).

4. An T, Yang H, Li G, Song W, Cooper WJ, Nie X. Kinetics and mechanism of advanced oxidation processes (AOPs) in degradation of ciprofloxacin in water. Appl Catal B-Environ 94:288-294 (2010).

5. Zhang $\mathrm{H}$, Huang C-H. Oxidative Transformation of Fluoroquinolone Antibacterial Agents and Structurally Related Amines by Manganese Oxide. Environ Sci Technol 39:4474-4483 (2005).

6. Watkinson AJ, Murby EJ, Costanzo SD. Removal of antibiotics in conventional and advanced wastewater treatment: Implications for environmental discharge and wastewater recycling. Water Res 41:41644176 (2007).

7. Nie X, Wang X, Chen J, Zitko V, An T. Response of the freshwater alga Chlorella vulgaris to trichloroisocyanuric acid and ciprofloxacin. Environ Toxicol Chem 27:168-173 (2008).

8. Kümmerer K, Al-Ahmad A, Mersch-Sundermann V. Biodegradability of some antibiotics, elimination of the genotoxicity and affection of wastewater bacteria in a simple test. Chemosphere 40:701-710 (2000).

9. Cunningham SD, Anderson TA, Schwab AP, Hsu FC. Phytoremediation of Soils Contaminated with Organic Pollutants. In: Donald LS, ed. Advances in Agronomy. Academic Press (1996).

10. Földváry CM, Wojnárovits $\mathrm{L}$. The effect of high-energy radiation on aqueous solution of Acid Red 1 textile dye. Radiat Phys Chem 76:14851488 (2007).

11. Kurucz CN, Waite TD, Cooper WJ. The Miami Electron Beam Research Facility: a large scale wastewater treatment application. Radiat Phys Chem 45:299-308 (1995).

12. R.J.Woods, A.K.Pikaev. Applied Radiation Chemistry. New York: John Wiley \& Sons,Inc.; (1994).

13. Spinks JWT, Woods RJ. An Introduction to radiation chemistry. Third ed. ed. New York: John Wiley \& Sons,Inc.; (1990).

14. Cooper WJ, Cadavid E, Nickelsen MG. Removing THMs from Drinking Water Using High-Energy Electron-Beam Irradiation. J AmWater Works Assoc 85:106-112 (1993).

15. Lin KJ, Cooper WJ, Nickelsen MG, Kurucz CN, Waite TD. Decomposition of aqueous solutions of phenol using high energy electron beam irradiation - A large scale study. Appl Radiat Isotopes 46:1307-1316 (1995).

16. Mak FT, Zele SR, Cooper WJ, Kurucz CN, Waite TD, Nickelsen MG. Kinetic modeling of carbon tetrachloride, chloroform and methylene chloride removal from aqueous solution using the electron beam process. Water Res 31:219-228 (1997).

17. Basfar AA, Khan HM, Al-Shahrani AA, Cooper WJ. Radiation induced decomposition of methyl tert-butyl ether in water in presence of chloroform: kinetic modelling. Water Res 39:2085-2095 (2005).

18. Buxton G, Greenstock C, Helman W, Ross A. Critical-review of rate constants for reactions of hydrated electrons, hydrogen-atoms and hydroxyl radicals $\mathrm{OH}^{-} \mathrm{O}^{-}$in aqueous-solution. J Phys Chem Ref Data 17:513-886 (1988).

19. Singh A, Kremers W. Radiolytic dechlorination of polychlorinated biphenyls using alkaline 2-propanol solutions. Radiat Phys Chem 65:467$472(2002)$

20. Mincher BJ, Curry RD. Considerations for choice of a kinetic fig. of merit in process radiation chemistry for waste treatment. Appl Radiat Isotopes 52:189-193 (2000).

21. Lee B, Lee M. Decomposition of 2,4,6-trinitrotoluene (TNT) by gamma irradiation. Environ Sci Technol 39:9278-9285 (2005).

22. Mincher BJ, Brey RR, Rodriguez RG, Pristupa S, Ruhter A. Increasing PCB radiolysis rates in transformer oil. Radiat Phys Chem 65:461-465 (2002).

23. Sánchez-Polo M, López-Peñalver J, Prados-Joya G, Ferro-García MA, Rivera-Utrilla J. Gamma irradiation of pharmaceutical compounds, nitroimidazoles, as a new alternative for water treatment. Water Res 43:4028-4036 (2009). 